\title{
INTEGRATION OF HELICOPTER ANNULAR COMBUSTION CHAMBER RIG IN PROPULSION SYSTEMS COURSE FOR GRADUATE STUDENTS
}

\author{
I. Al-Asmi ${ }^{1}$, A. Vandel ${ }^{1,2}$, G. Cabot ${ }^{2}$, F. Grisch ${ }^{1,2}$, V. Moureau ${ }^{2}$, N. Savary ${ }^{3}$, S. Richard ${ }^{3}$, B. Renou ${ }^{1,2}$ \\ 1) INSA Rouen Normandie, Energy and Propulsion Department, \\ Avenue de l'Université, BP08, \\ 76801Saint Etienne du Rouvray, France \\ 2) CORIA UMR6614, Normandie Université \\ Avenue de l'Université, BP08, \\ 76801Saint Etienne du Rouvray, France \\ 3) SAFRAN Helicopter Engines \\ Avenue Joseph Szydlowski, \\ 64510 Bordes, France
}

\begin{abstract}
The integration of graduate research in the training of engineering students has demonstrated a significant increase in learning efficiency, by giving them a practical experience with real industrial issues. The department of Energy and Propulsion of National Institute of Applied Sciences in Normandy, a French Engineering School, continues to implement the latest fully instrumented facilities in their field to initiate the students to inquirybased education courses. In this type of education, they are carrying out a series of tests, learning how to handle equipment, control and monitor tests, extract results and ultimately analyze and present them in technical reports. This paper addresses how the Helicopter Annular Combustion Chamber test facility has been integrated in the Propulsion systems engineering course sequence. The Annular Combustion Chamber kindly provided by SAFRAN Helicopter Engines was progressively incorporated and instrumented in a dedicated test facility by the students themselves along the last 8 years. Now, this laboratory practical work offers the students the possibility to interactively learn about the operation of a combustion chamber inside a helicopter engine at various air/fuel flow rates. Students learn how to determine the limits of ignition/non-extinction as a function of the entry
\end{abstract}

air-flow rate. In addition, this facility is equipped with highlevel instrumentation that allows to measure the different flow rates, pressure, temperature inside and outside the annular chamber, and the pollutant emissions at the exit. Results provided by students help to build a comprehensive knowledge base of combustion phenomena inside a turbojet engine. It is to be mentioned that this educational facility is unique in its category, from the point of view of results accuracy, instrumentation level and realistic operating conditions.

\section{INTRODUCTION}

Based on education development literature, which is confirmed by statistics, integrating research into undergraduate engineering curricula, permanently in contact with an industrial partnership, is essential for education institutions to uphold a position of world leadership in all aspects of science. This form of modern education can bring benefits to all parts, students, laboratories and engaged companies. Boyer commission [1] suggested reinventing undergraduate education by making research-based learning the standard form of education. They believe that traditional lecturing in universities should be replaced by a culture of inquiries, in which students and teachers share an adventure of 
discovery. The National Science Foundation [2] recommended faculties to use innovative techniques such as classroom research, learner-centered instruction and team study. Moreover they encouraged industry to invest in the development of nation's students, to partner with education and educators to become open to expertise from business sector professionals. National Research Council [3] requested all institutions of higher education to provide diverse opportunities for all students to learn mathematics, engineering and technology as practiced by scientists and engineers, and as early in their academic careers as possible. Kinkead [4] explained how students share an enthusiasm for hands-on learning that extends classroom knowledge to scholarly application due to inquiry-based learning. Teachers, on the other hand, enjoy working with energetic undergraduates, and seeing their theories tested in the laboratory [5]. Kardash [6] reported the need for models of learning in the research laboratory to enhance interns' abilities to engage in the "real work" of scientists by learning to conceptualize real scientific problems, design experiments, perform skills necessary to analyze and collect data and draw conclusions. Zydney et al. [7] confirmed that undergraduate research experience in engineering helps to develop specific area of specialization, enhance communication, technical and critical skills, and improve human creativity. He also surveyed engineering alumni at the Delaware University and concluded that a very high percentage (92.4\%) of the alumni who had participated in undergraduate research evaluate this experience as "very" or "extremely" valuable to their career [8]. Morley et al. [9] found that $92 \%$ of the participants in a summer research program in electrical engineering at Georgia Tech were either enrolled in a graduate school or were planning to enroll within the next two years. Furthermore, industrial partners are also beneficiaries since they are able to train their future experts, and may accomplish a part of their missions with minimized costs. Laboratories can take advantage of the latest technologies derived from the industry in order to keep themselves up-to-date and to provide attractive tasks for their future graduate students.

The Helicopter Annular Combustion Chamber (ALICE) test facility was designed and built for the training of engineering students in propulsion systems courses. This academic training is delivered by the department of Energy and Propulsion of INSA (National Institute of Applied Sciences) Rouen Normandie, a French Engineering School. The INSA network is the largest group in France for training engineers. Each year, 10\% of French engineers graduate from one of INSA institutions. INSA Rouen Normandie offers an integrated degree program with 10 semesters of study leading to the French 'Diplôme d'Ingénieur', equivalent to a Master's degree. Energy and Propulsion (EP) department forms 60 students each year in the different specializations (Aeronautics, Propulsion systems and Sustainable energy as shown in Fig. 1) from whom $20 \%$ build their career in the aeronautic field (Airbus, Safran, Rolls-Royce..), with more than $20 \%$ (on average) continuing their doctoral studies.

As shown in Fig. 2, Propulsion Systems specialization allow students to have strong knowledge in modeling, simulation, combustion, fluid mechanics in jet engines, and other engineering sciences related to the propulsion systems (Vibration, power electronics etc..) [10]. One of the main teaching units in this course is the aeronautic propulsion, in which students carry out 95 hours of theoretical classrooms. The ALICE practical exercise

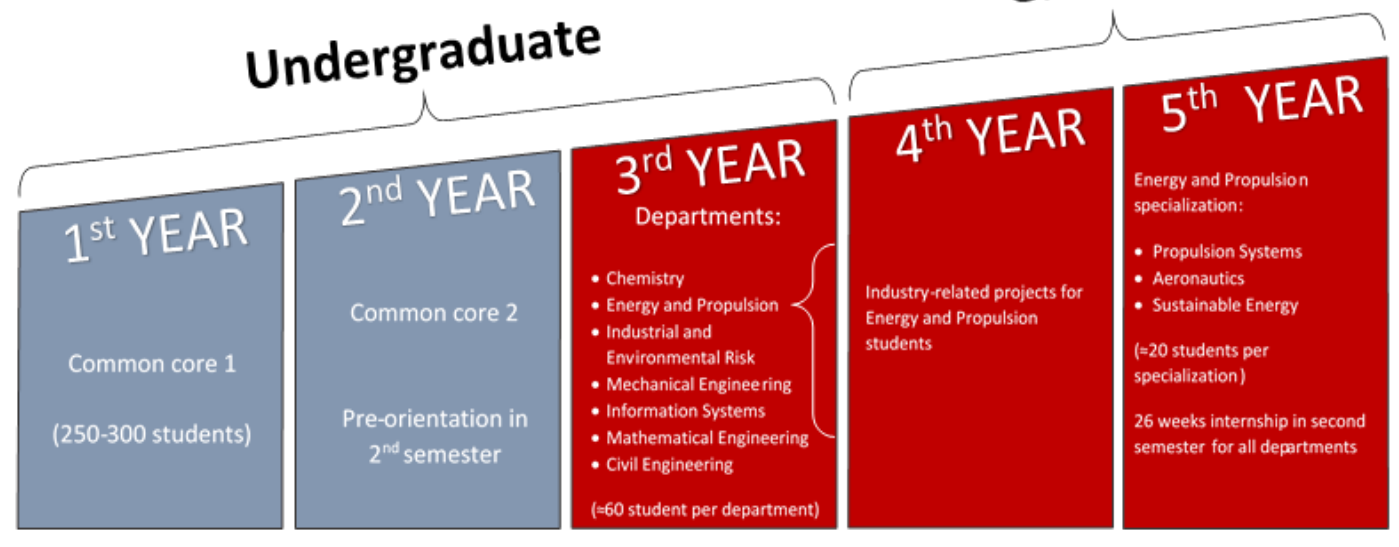

FIGURE 1. SIMPLIFIED DIAGRAM OF INSA-NORMANDIE ENGINEERING CURRICULUIM 
comes in the same unit to illustrate the theory, learnt in classrooms, via a hands-on approach.

Over the latest years, INSA Rouen Normandie has established more than 50 partnerships with key companies, as SAFRAN Aircraft Engines, SAFRAN Helicopter Engines, EDF and TOTAL for instance. Moreover, a 4-years joint-research program between SAFRAN, INSA Rouen Normandie, CORIA Research Laboratory and ANR (French National Agency of Research) has just started to develop innovative combustion technologies by combining both fundamental and applied research in aircraft engines (Chaire PERCEVAL). Those relations are a real source to exchange skills and experience between professors and industrial experts, to hold conferences on the latest challenges in the Research and Technology domains and to provide interesting internships and job opportunities for the future engineers [11].

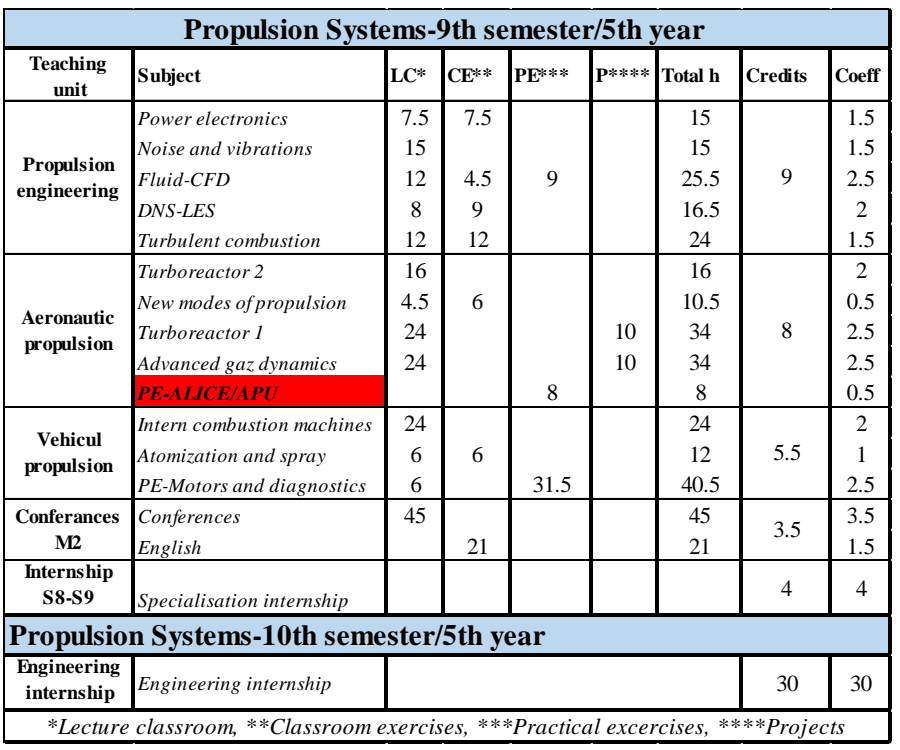

\section{FIGURE 2. FIFTH YEAR PROPULSION SYSTEM COURSES}

In this context, the ALICE project started 8 years ago. ALICE is a multi-year project which demanded time, cost and resource management, in order to accomplish a highly-qualified technical and scientific mission. ALICE results from the strong industrial partnership and multiple interactions and exchanges between the CORIA laboratory, INSA students and SAFRAN Helicopter Engines. In October 2009, SAFRAN HE delivered a combustion chamber equipped with fuel injectors. For several years, fourth year students in the context of their mandatory industry-related project, or as trainees were responsible of achieving full-instrumented and automated test bench (their works will be presented in the "Technical
Description" section), by following "iterative design projects" method, with the following final objectives:

- Prepare and involve students in the implementation of test bench, which requires many engineering skills as CAD, aerodynamics, combustion, metrology and monitoring.

- Introduce efficient working methods, such as project management, progress reporting, and regular communication with the lab for better management of human, technical and financial resources.

- Conduct tests in the aeronautic-atmospheric combustion chamber primarily for teaching, but also for professional reasons according to the need of SAFRAN-HE.

After eight years of sequential work, with more than 35 students (mainly graduate students), 10 meetings and 5 external visits to SAFRAN, ALICE academic test rig was implemented and today it continues to evolve year after year.

Literature shows that there is a lack of similar academic laboratory exercise in the curriculum of engineering students. However many test rigs have been installed in universities over the last years, to meet the increasing demand for more research in the undergraduate and graduate courses. Students from KTH University (Sweden) [12] showed how a remote pump facility has been successfully integrated in the turbomachinery course. Aeronautics Institute of Technology (ITA) [13] developed a project-based learning in turbopump discipline via a booster turbine. The Department of Aeronautics at the United States Air Force Academy (USAF) [14] integrated a turbine cascade facility into an undergraduate thermo-propulsion sequence. In 2012, undergraduate students of six universities in USA [15] participated in designing a thrust vectoring system for a jet engine. They all confirmed that their experience was very beneficiary and called more universities to get together in a friendly competition with industry and/or government and/or academic sponsorship to increase project-based learning experiences for future engineers [16] [17]. Comparing ALICE to other academic test rigs in the literature, designed and used by engineering students, this bench is very specific and unique due to the following reasons. To our knowledge, ALICE is the only one of its type to be used in advanced combustion in helicopter engine for teaching purpose. The modular facility allows conducting ignition/non-extinction and pressure drop measurement tests, analyzing the exhaust gases, characterizing the flame propagation and mapping the outlet surface temperature for a wide diversity of combustion chambers with real operating conditions and 
for different mixture equivalence ratios. The facility is also highly automated and instrumented in order to program sets of tests, also to view and register simultaneously the flame video in stationary or ignition/non-extinction conditions, other physical and monitoring parameters. The whole tests are carried out by INSA students with the support of teachers and researchers and with the validation of SAFRAN HE engineers. Finally, it allows the participation in future engineers training and conducting tests according to SAFRAN HE needs on industrial scale. Table 1 shows a comparison between ALICE and other advanced academic facilities founded in literature, which are used in teaching propulsion courses [15] [18] [19] [20].

\begin{tabular}{|l|l|l|l|l|l|}
\hline Facility name & ALICE & $\begin{array}{l}\text { Thrust system- } \\
\text { SJE }\end{array}$ & $\begin{array}{l}\text { Mini } \\
\text { Olympus }\end{array}$ & MW-54 & $\begin{array}{l}\text { Mini-Lab Jet } \\
\text { Engine }\end{array}$ \\
\hline $\begin{array}{l}\text { Facility } \\
\text { designers }\end{array}$ & INSA USA & $\begin{array}{l}\text { AMT } \\
\text { Company } \\
\text { universities } \\
\text { ds) }\end{array}$ & $\begin{array}{l}\text { W. Michigan } \\
\text { University }\end{array}$ & $\begin{array}{l}\text { Turbine- } \\
\text { technologies } \\
\text { Company }\end{array}$ \\
\hline $\begin{array}{l}\text { Field } \\
\text { application }\end{array}$ & $\begin{array}{l}\text { Annular } \\
\text { Combusti } \\
\text { on } \\
\text { Chamber }\end{array}$ & $\begin{array}{l}\text { Turbojet } \\
\text { engine }\end{array}$ & Jet engine & Turbojet engine & Jet engine \\
\hline $\begin{array}{l}\text { Academic } \\
\text { institution }\end{array}$ & $\begin{array}{l}\text { INSA- } \\
\text { France }\end{array}$ & $\begin{array}{l}6 \\
\text { universities }\end{array}$ & $\begin{array}{l}\text { U. } \\
\text { Politécnica } \\
\text { Madrid }\end{array}$ & $\begin{array}{l}\text { W. Michigan } \\
\text { University }\end{array}$ & $\begin{array}{l}\text { Israel Institute } \\
\text { of Technology }\end{array}$ \\
\hline $\begin{array}{l}\text { Industrial } \\
\text { partnership }\end{array}$ & $\begin{array}{l}\text { SAFRAN- } \\
\text { HE }\end{array}$ & No & No & $\begin{array}{l}\text { Wren T. } \\
\text { Company }\end{array}$ & No \\
\hline Scale & Industrial & Lab & Lab & Industrial & Lab \\
\hline Modularity & Yes & No & No & No & No \\
\hline $\begin{array}{l}\text { Real operating } \\
\text { conditions }\end{array}$ & Yes & No & No & Yes & No \\
\hline $\begin{array}{l}\text { Instrumen- } \\
\text { tation }\end{array}$ & High & High & Low & High & Low \\
\hline $\begin{array}{l}\text { LabVIEW } \\
\text { monitoring }\end{array}$ & Yes & No & No & Yes & Yes \\
\hline Automation & High & No & Low & Low \\
\hline
\end{tabular}

TABLE 1. ACADEMIC TEST FACILITIES FOR PROPULSION ENGINEERING

This paper aims, in the first place, to highlight the accomplished work of $4^{\text {th }}$ year engineering students and other trainees in order to achieve the facility that will be presented below. Moreover, the intended learning outcomes of the laboratory exercise will be discussed, besides, the procedures of the exercise will be detailed. An illustration of the experimental results, delivered by the fifth-year students as part of their propulsion system laboratory exercise, will be shown and analyzed. Finally, assessments of outcomes will be presented on two levels in the last section; outcomes of the test rig construction as a $4^{\text {th }}$ year mandatory industry-related project and of the laboratory exercise for the $5^{\text {th }}$ year students.

\section{PEDAGOGICAL CONCEPT}

ALICE test cell is a part of the propulsion system course. Following inquiry-based education model as described in the first part, it allows students to apply theoretical concepts taught in courses on real situations so that they get a concrete experience. At the same time, those fields of application are research subjects in industrial groups to ensure student motivation, create strong professional relationships and make them up-todate on the latest market issues. The main intended learning outcomes of this laboratory exercise are the following:

- To understand the concept of turbojet engine inside a helicopter.

- To understand the concepts of combustion inside a helicopter engine.

- To understand the concepts of running an engine at various operating points by varying the fuel air ratio and the air mass flow rate.

- To understand the phenomena of ignition/nonextinction limit of flame and its effects on the design and the operability of the combustion chamber.

It is to be noted that this test facility continues to evolve being part of students annual projects, where they spend four hours a week and for a total duration of eight months, in continuity with last years to develop new tools that can be interesting for future missions. As an example, in 2017/2018, students are working on the implementation of a series of motorized thermocouples that will give the possibility to measure the temperature homogeneity and the gravity effects at the exit of the annular combustion chamber.

\section{TECHNICAL DESCRIPTION}

\section{CHARACTERISTIC AND OPERATING RANGE}

An overview of the ALICE test bench is reported in Fig. 3. ALICE is composed of a $20 \mathrm{~kW}$ ventilator to supply air and overcome the pressure drop in the installation. In order to satisfy the needs of SAFRAN HE, the test facility has a $40 \mathrm{~kW}$ preheating system, which allows reaching an inlet temperature up to $540 \mathrm{~K}$. The test cell features a kerosene system (tanks, pumps, electro-valves...etc.) to ensure the fuel distribution. The combustion chamber is supplied by two fuel rings equipped with 6 fuel injectors each and can simulate helicopter real operating conditions, with a maximum air flow rate of $300 \mathrm{~g} / \mathrm{s}$, and a global fuel air ratio (FAR) of $1 / 45$, which correspond to a kerosene mass flow rate of $6 \mathrm{~g} / \mathrm{s}$. In addition, two successive diffusers are implemented between the air supply and the combustion chamber to ensure a perfectly axial flow with a negligible azimuthal velocity component. The combustion chamber can be ignited by two spark-plugs located near 
two specific ignition injectors supplied by an independent kerosene inlet.

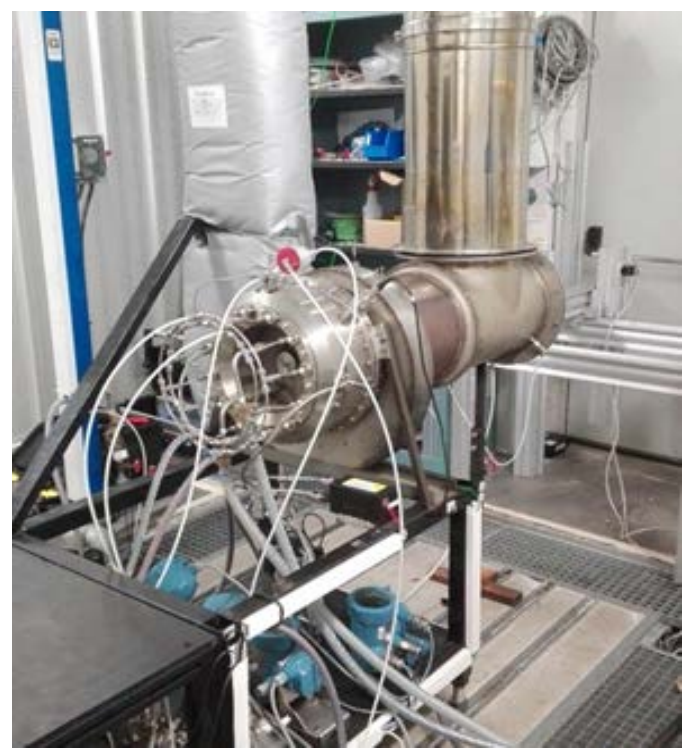

FIGURE 3. ALICE TEST BENCH

The modularity of ALICE allows testing different type of combustion chambers by simply replacing the existing one. Finally, the downstream part of the combustion chamber is the exhaust that contains 3 thermocouples to measure the outlet temperature. Figure 4 summarizes the main parts of the facility as well as the different measurement systems.

\section{AIR INLET}

ALICE is operated through an "open" cycle, which means that the air used in the combustion is taken from outside using a fan. Air is sent in a vertical pipe, which contains a Venturi flow-meter used to monitor the airflow. At the end of the pipe, air crosses the preheating system to insure a stable combustion with an inlet air temperature ranging from $330 \mathrm{~K}$ to $540 \mathrm{~K}$. After being preheated, air enters inside the combustion chamber throughout two successive diffusers (Figure 5). Indeed, in real helicopter engine, air is usually introduced into the combustion chamber by means of the last centrifugal compressor stage. In ALICE, this step is guaranteed by two diffusers. These later were studied and simulated in real conditions so that pressure and velocity fields inside the combustion chamber would be homogenous, fluid steering angle must be lower than $10^{\circ}$, pressure drop should be minimized and the component should handle the preheating of air. The developed device was obtained by numerical simulation

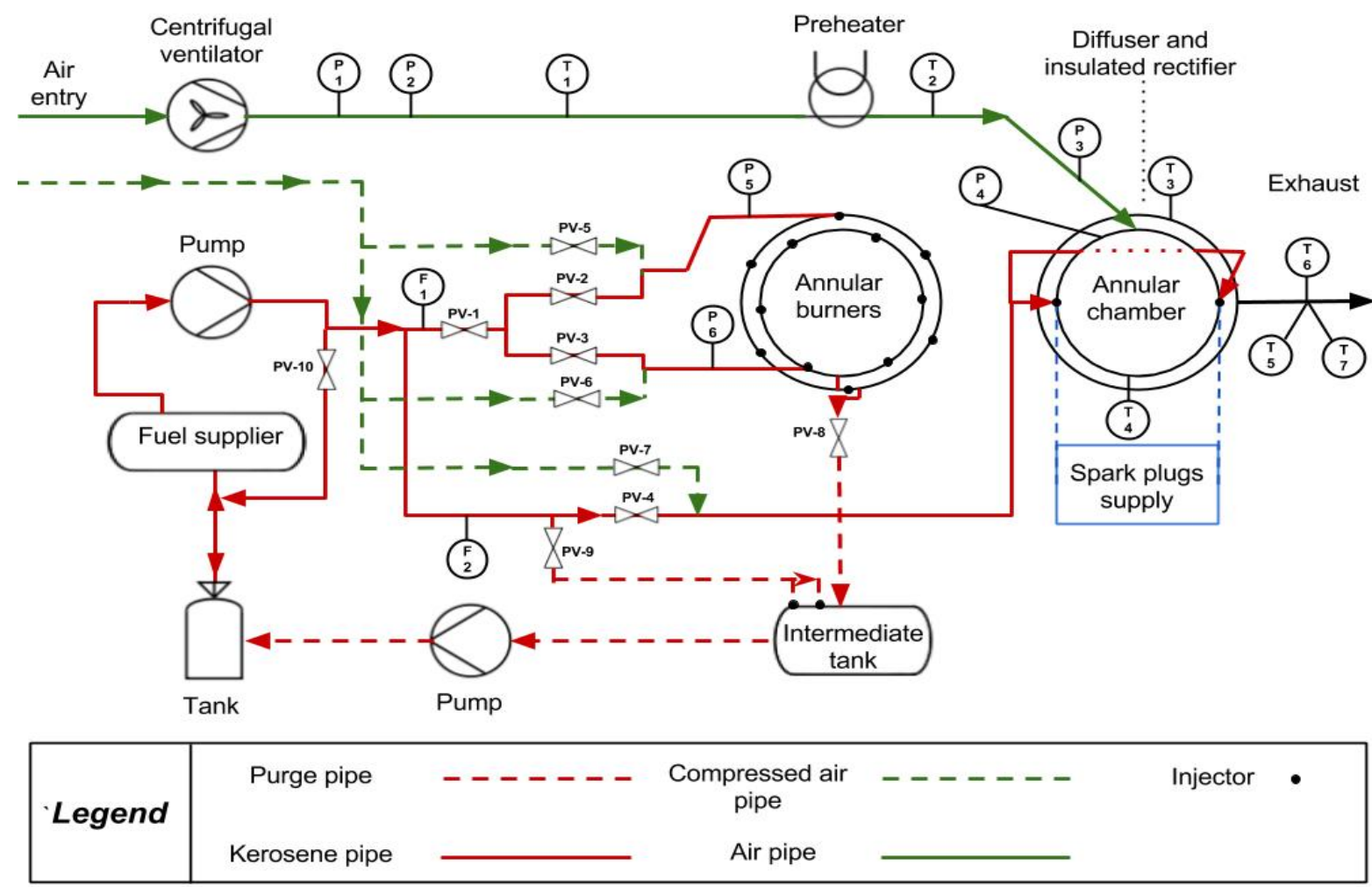

FIGURE 4. SYNOPTIC DIAGRAM OF ALICE FACILITY 
that allows determining the optimal geometrical design inside the combustion chamber.
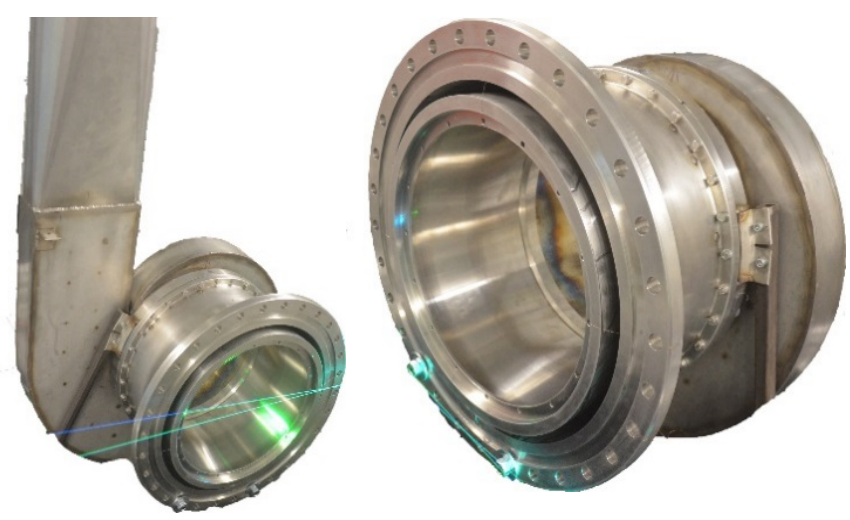

FIGURE 5. DIFFUSER

\section{KEROSENE INLET}

Kerosene feeding lines are divided into 3 subsystems as represented in Fig. 6 . The first system is used to pressurize a manifold to ensure a given volume of fuel at a constant pressure. Indeed, kerosene is sucked out of the fuel tank (200 L) by the feeding pump ( $24 \mathrm{~V})$. Later fuel goes through a filter to eliminate all the impurities before filling up the manifold. The latter is then used to feed the chamber injectors with fuel. A volumetric pump (220 V) is used to fuel both the 12 pre-spray injectors and the 2 ignition injectors. It is to be noticed that, in the kerosene loops, the Kammer-valve is responsible for controlling the fuel rate. Inside the ignition loop, kerosene is pumped under fixed pressure of 10 bars. As a result, the fuel is sprayed inside the atomizer and burned due to the sparks produced by the spark plugs. As for the pre-spray injectors, the loop is controlled under a determined kerosene flow rate. A purge system is also present on the feeding and ignition circuits, which makes it possible to control the flow of kerosene with high accuracy. While waiting for the needed kerosene flow to be reached, the fuel continues to circulate in the circuit but flows through the purge system. As soon as the regulation is optimal, the purge system is cut off by a pneumatic valve and the desired flow rate is then obtained in the injectors.

\section{Combustion Chamber AND FUEL INJECTORS}

The multi-perforated annular combustion chamber has been lent by SAFRAN HE as presented in Fig. 7. In the bottom, there are 12 holes equally spaced allowing the location of the 12 injectors plus 2 holes for the ignition injectors. Primary and secondary dilution holes are situated all around the chamber downstream the combustion. Air recirculation zones are created in the bottom of the combustion chamber by different air injections holes and deflection plates to stabilize the flame at the injector exit. In order to protect the combustion chamber and to prevent from temperature damage, the minimum Fuel Air Ratio is fixed to $1 / 50$. In nominal operating point (Air flow rate of $300 \mathrm{~g} / \mathrm{s}$ and $F A R=1 / 50$ ), the pressure drop in the chamber is equal to 30 mbar which represents $3 \%$ of the global pressure difference. Fuel injection is achieved by means of two independent systems, including different pipe, operating pressure and

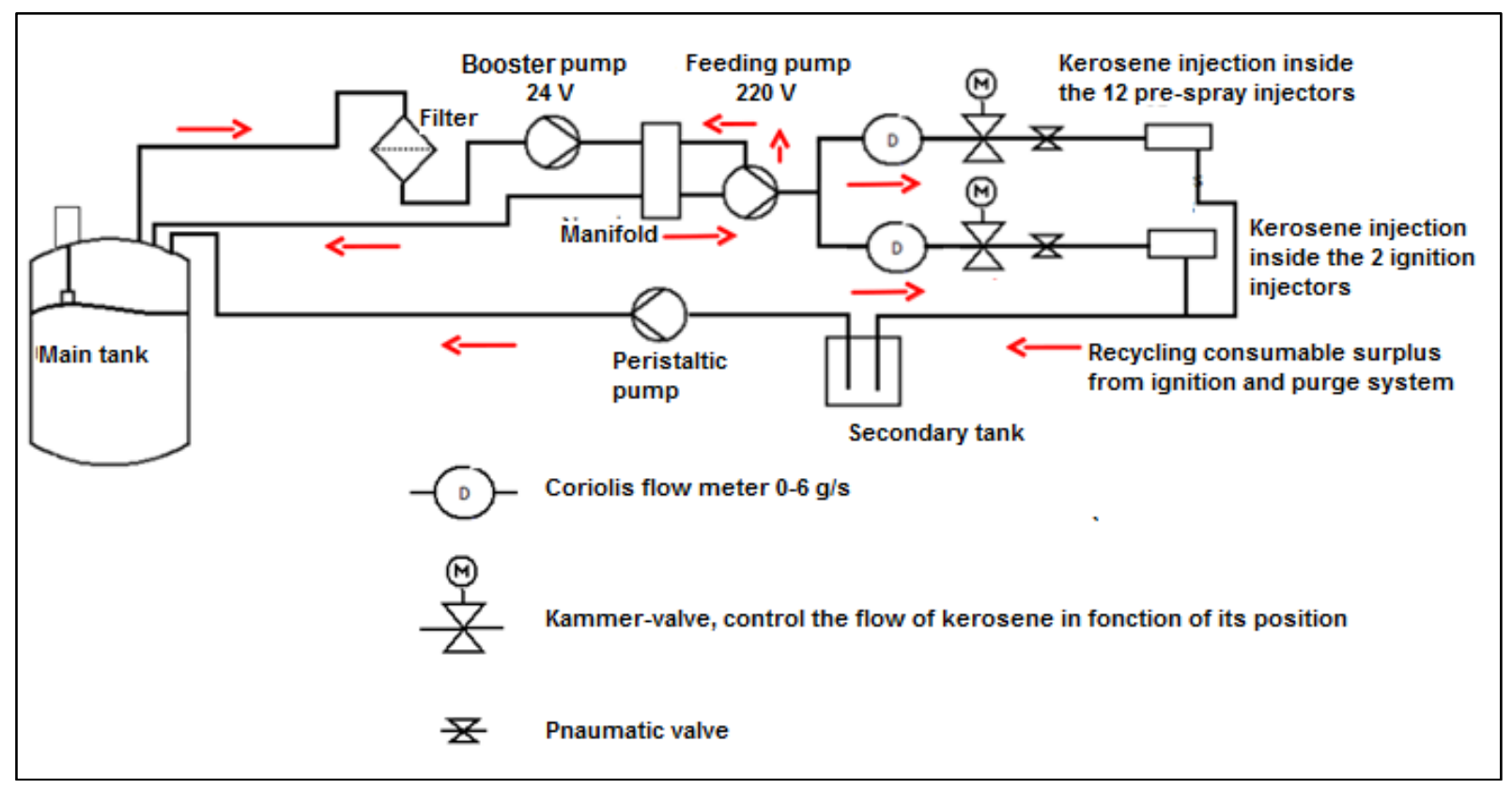

FIGURE 6. KEROSENE FEEDING LINES, P\&ID 
fuel injectors. The first one is achieved by the 2 pressurized fuel injectors (Fig. 8), where the fuel is atomized by the high pressure drop as explained previously. In this system, ignition injectors are displayed on both sides of the annular chamber, at the same height.
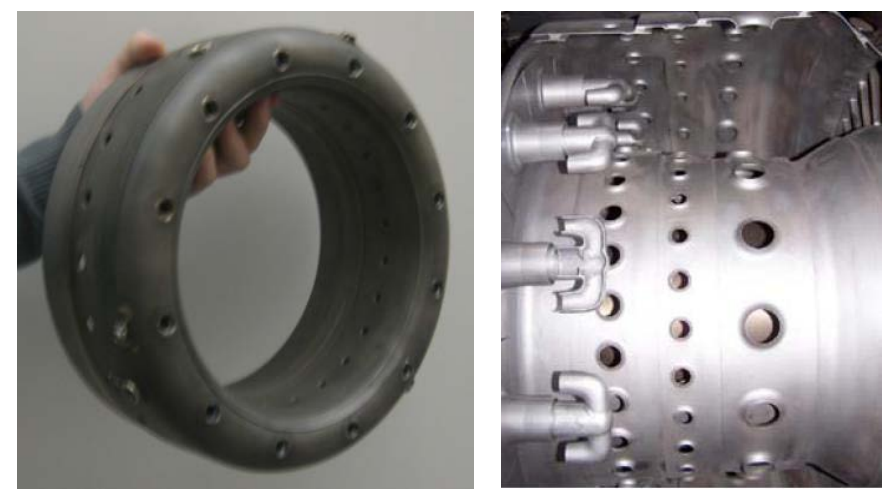

FIGURE 7. ANNULAR COMBUSTION CHAMBER

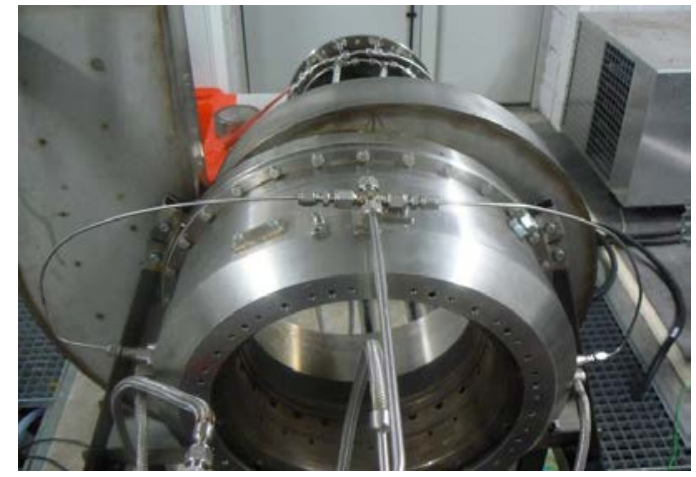

FIGURE 8. IGNITION INJECTORS

The second one is composed of 12 pre-spray injectors given by SAFRAN HE. In such injector, fuel is partly vaporized into some air into tubes that are immersed in the flame. The injected fuel-air mixture is heated by the tube walls and, under ideal conditions, emerges as a mixture of vaporized fuel and air (Fig. 9). The advantage of this kind of injection is to permit a good quality of combustion, without a huge pressure of kerosene [21]. Moreover, this system offers the double number of injection points compared to standard injection system. Indeed, the 12 injectors are placed on two independent annular injection rings, each ring having 6 equally spaced fuel injectors. The combustion chamber can then be supplied by 6 or 12 injectors according to user's needs.

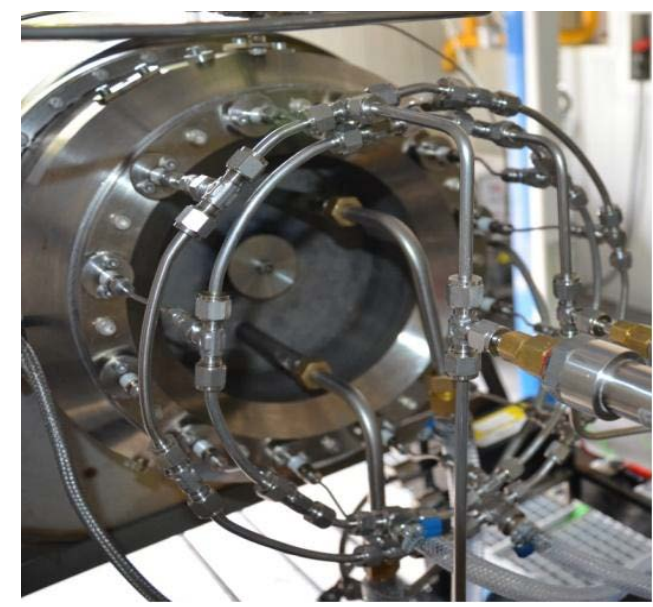

FIGURE 9. FUEL RINGS WITH THE 12 INJECTORS

The main difficulty to reproduce same conditions as for real helicopter engine was the equality of kerosene flow inside all injectors. In reality, the fueling process inside the ALICE starts from the lowest point inside the vertical combustion chamber, and the kerosene flow is always higher in the low-level injectors compared to high-level injectors. To avoid that, a pressure drop was created by adding supports to injectors so that the kerosene flow would be equal in each injector.

\section{EXHAUST}

This part is responsible for evacuating exhaust gases and rejecting them into the atmosphere. In addition, it is the place where longitudinal and tangential velocity of combustion products is being measured. Moreover, exhaust pipe permits video-recording of the flame inside the combustion chamber as shown in Fig. 10. Due to the high combustion temperature and the mechanical properties of the materials, the exhaust gases need to be cooled to avoid the damage of the structure. For that, many techniques where studied and the technique of 'film cooling' combined with a water exchanger were finally chosen for cost and time reasons. To obtain the lowest temperature near the walls with the film cooling, many simulations were carried out with different conditions. Those two chosen techniques offer a maximum wall temperature lower than $800 \mathrm{~K}$. 


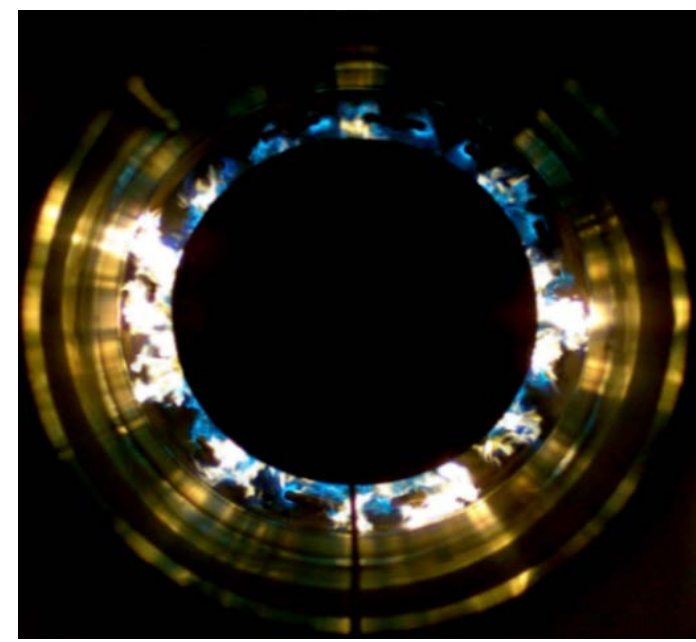

FIGURE 10. FLAME CAPTURED FROM THE EXHAUST PIPE

\section{MEASUREMENT AND INSTRUMENTATION}

ALICE bench includes a lot of instrumentation and many valves, which are responsible of measuring and controlling the fluid. Table 2 shows different instrumentation on ALICE circuit.

\begin{tabular}{|c|c|c|c|c|}
\hline $\begin{array}{l}\text { Measured } \\
\text { quantity }\end{array}$ & $\begin{array}{l}\text { Used } \\
\text { technology }\end{array}$ & Location & Precision & $\begin{array}{l}\mathrm{N}^{\circ} \\
\text { sensors }\end{array}$ \\
\hline \multirow[t]{4}{*}{$\begin{array}{l}\text { Static } \\
\text { Pressure }\end{array}$} & $\begin{array}{l}\text { Differential } \\
\text { pressure }\end{array}$ & Air circuit & +-0.1 bar & 2 \\
\hline & $\begin{array}{l}\text { Differential } \\
\text { pressure }\end{array}$ & $\begin{array}{l}\text { Kerosene } \\
\text { circuit }\end{array}$ & & 2 \\
\hline & $\begin{array}{l}\text { Differential } \\
\text { pressure }\end{array}$ & $\begin{array}{l}\text { Air } \\
\text { distribution } \\
\text { crown }\end{array}$ & & 1 \\
\hline & $\begin{array}{l}\text { Differential } \\
\text { pressure }\end{array}$ & $\begin{array}{l}\text { Combustion } \\
\text { chamber }\end{array}$ & & 1 \\
\hline Temperature & & & $+-1^{\circ}$ & $>7$ \\
\hline Position & $\begin{array}{l}\text { Pneumatic } \\
\text { valve }\end{array}$ & $\begin{array}{l}\text { Kerosene } \\
\text { circuit }\end{array}$ & $0.5 \%$ & 9 \\
\hline \multirow[t]{2}{*}{ Flow } & $\begin{array}{l}V \text {-cone flow } \\
\text { meter }\end{array}$ & Air circuit & $0.5 \%$ & 1 \\
\hline & $\begin{array}{l}\text { Coriolis flow } \\
\text { meter }\end{array}$ & $\begin{array}{l}\text { Kerosene } \\
\text { circuit }\end{array}$ & $0.1 \%$ & 2 \\
\hline $\begin{array}{l}\text { Flame } \\
\text { emission }\end{array}$ & Fast camera & Exhaust & $\begin{array}{l}\text { x36 } \\
\text { zooms }\end{array}$ & 1 \\
\hline Flow velocity & LDV Tech & Exhaust & & 1 \\
\hline
\end{tabular}

TABLE 2. INTRUMENTATION TABLE

\section{CONTROL SYSTEM}

The bench is driven by the user/machine interface LabVIEW. The software was chosen for the powerful performances and the wide-range of functionalities. Figure 11 shows the front panel and result screens that LabVIEW program gives.

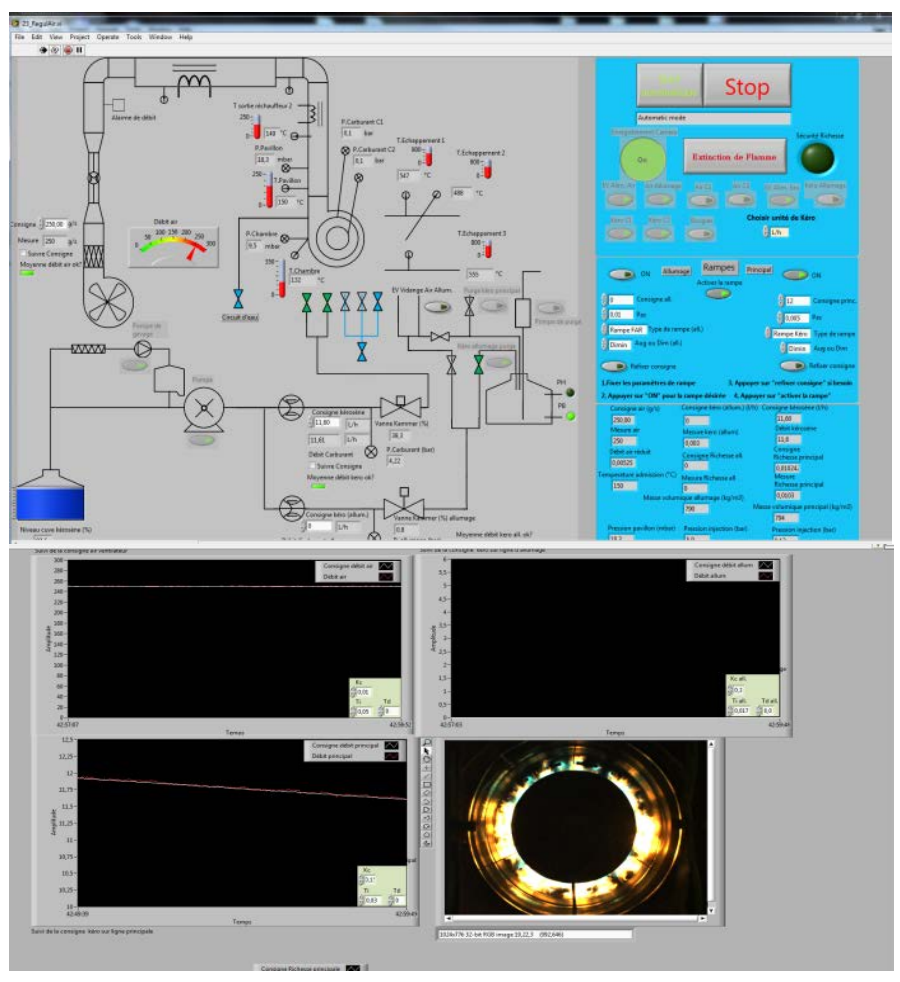

FIGURE 11. LABVIEW USER INTERFACE

We can monitor in real time the important parameters like kerosene and airflow, the equivalence ratio, the state of the burners thanks to the electro valves and the fast camera, as well as the temperatures in the key places of our system. This allows to have a real time tracking and be able to detect any abnormal behavior. Two test modes are available: manual mode and automatic mode. The manual mode allows the control of all parameters instantaneously. This is typically a program of an industrial use (procedures done by SAFRAN HE ....). However, this mode is mainly used for small tests or for additions of features. Indeed, it is preferred to use an automatic mode, where it is possible to program in advance the different steps of the test, then the software manages them automatically (photo interface). This allows the execution of complicated tests such as the non-extinction/ignition limits, pressure drop or exhaust gases analysis. In this way, users are able to automate the procedures carried out in industry, in order to make them more precise and efficient. In fact, the highly 
accurate acquisition device is able to track information by the millisecond, so that repetitive manipulation can be achieved. This option is precious for the statistical studies on combustion phenomena. In all cases, LabVIEW offers the opportunity to save and analyze data in order to make observations and conclusions on combustion phenomena in a helicopter jet engine.

The LabVIEW environment was prepared for use in two modes: student and expert, both modes are userfriendly. Student mode is the mode used in the practical work of 5th year students; it restricts access for some functionalities while still allowing students to determine the limits of extinction and ignition tests. The expert mode allows fine-tuning of the program and controlling more parameters, which are not needed by students for the experimental exercise.

In summary, ALICE is a modular and highly instrumented-automated bench, designed to perform nonextinction and ignition tests for diverse operation conditions on industrial scale and to determine pressure drop for a wide diversity of combustion chambers. Nevertheless, ALICE is able to analyze exhaust gases for combustion optimization, to calculate flame propagation characteristic time between injectors by means of highspeed camera and to map the surface temperature of the combustion chamber outlet.

\section{DESCRIPTION OF THE LABORATORY EXERCISE}

The helicopter combustion chamber test cell exercise has been introduced for the first time in turbojet engine course in INSA in 2015. Nearly 20 students train on this facility every year, supervised by a teacher-researcher who has participated in the creation of the test cell. The exercise includes mainly three phases: preparation, experience and reporting with total spent time of 8 hours per person. A group of students work together to conduct the experience and to report the results following the same methodology defined by the laboratory. In order to prepare the exercise, students are asked to review advanced combustion theories and turbojet courses covered in their class. The Helicopter combustion chamber test cell exercise consists of a series of tasks to be performed in groups. A lecture is given to students to define the objectives and to provide important information for the progress of the exercise. The tasks of the laboratory exercise are the following:

- Read the laboratory notes and the practical work subject

- Keep in contact with other group members in order to plan and spread tasks for an efficient work
- Perform the test cell activity

- Post-process the collected data and write a common report

The preparation phase is an important step to ensure that students have the adequate knowledge, and to illustrate class lessons inside a practical environment with observations and comparisons between theoretical and practical conclusions. Two hours is the average time for this step, in which students are asked to work independently in advance. The laboratory activity and the report writing have to be conducted by a group of up to 3 students. Groups are decided by the course responsible in order to ensure diversity in each. From previous experience, 4 hours is an adequate time to perform the required tasks. At the beginning of the laboratory exercise, the responsible professor devotes a few minutes for each group, to introduce briefly the materials, the features of the test cell, the different screens of the user interface and their usage, how to program a set of tests and how to postprocess the collected results. At the reserved time, each student should participate in the achievement of every task including the computer and data manipulation, observations and conclusions. The test cell activity consists of 5 main parts, each of them includes few tasks that take more or less time to accomplish.

\section{Installation description}

In the beginning, students describe the global architecture of the test cell; air circuit, fuel circuit, injection system, startup circuit and exhaust circuit. In addition, they study the facility-operating mode and the measuring principle of each component of the test cell and estimate their measurement accuracy. Later on, they illustrate the facility in a global schematic way.

\section{Facility Control and Instrumentation}

In this part, their mission is to identify the different sensors (thermocouple, pressure sensors...etc.), to describe the different actuators of the test cell (electrovalves, pneumatic-valves) and their essential role in the management of the fuel circuit, during the different phases of the exercise. Students should determine the electrovalves position during the different phases of test and compare the used devices, for measuring and controlling, with other technologies in the market

\section{Graphical interface and monitoring system}

Identify the different units that allow the data acquisition (tension, intensity, temperature, inlet, outlet) 
and get familiar with the different operational mode of the graphical interface (Manuel, automatic and synoptic view).

\section{The facility launch}

In order to startup the facility, students should define the automatic procedure to enable the launch of the combustion chamber, in accordance with SAFRAN HE requirements. After the end of the activity, each group is requested to write a 15 pages report. The report should include an introduction, a description of combustion chamber inside the turbojet, a definition of the facility and its specific features, experimental results, a comparison and conclusions taking the theory shown in class into account. At the end, reports are submitted via e-mail to the responsible of the course with a delay of one week. This represents a tool for the professors to have a feedback on the exercise, to ensure that students have acquired the intended learning outcomes, and to make further improvements in the future.

\section{Experimental results}

As the whole activities starting from the installation description up to the facility launch were detailed in the previous section, this part will focus on the observations of the experimental measurement session. Nowadays, turbomachinery industries are spending great deal of money on research to understand better combustion. The understanding of ignition/non-extinction limits is a big challenge for future high-performance and environmentfriendly propulsion. The ALICE test bench provides the opportunity to simulate the operation of the helicopter engine in real conditions, and to obtain specific information on those limits. The point of this section is to describe the results of lean blowout test, taking place inside a combustion chamber under determined conditions. The following test has been conducted using fixed airflow of $250 \mathrm{~g} / \mathrm{s}$, with an entry air temperature of $150^{\circ} \mathrm{C}$. The basic kerosene flow is $12 \mathrm{l} / \mathrm{h}$, and decreases at a sustained rate of $1 \mathrm{l} / \mathrm{h}$ every $28.5 \mathrm{~s}$ (Fig. 12). When a flow rate of $5 \mathrm{l} / \mathrm{h}$ is reached, the decrease in value becomes constant and equal to $0.001 \mathrm{l} / \mathrm{h} / \mathrm{s}$. Based on SAFRAN HE criterion, the non-extinction limit is simply the moment when all the injectors are switched off. A scientific camera has been installed in front of the quartz window to visualize the flame during the test phase. The flame video is synchronized with data recording, including the flow rates, temperatures, pressures, and the electro-valves values. This provides users with a rebuilt video (Fig. 13) to make easier the extraction of important results, and simplify the diffusion of information between the students and SAFRAN HE.

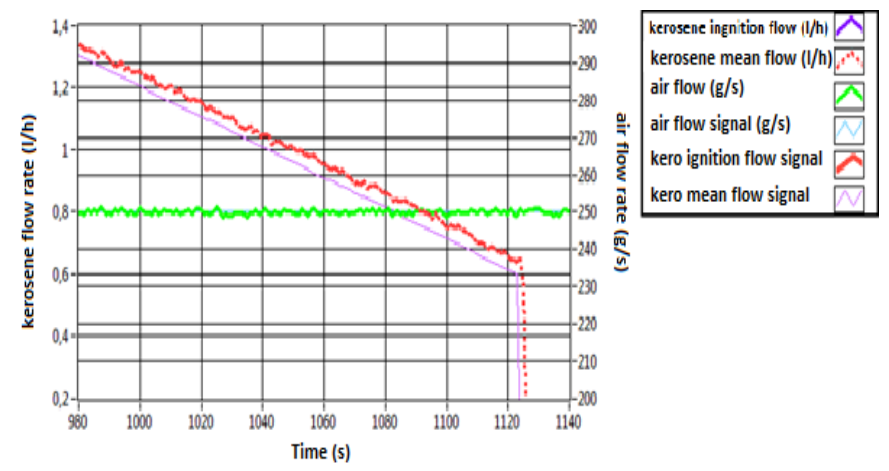

FIGURE 12. AIR AND KEROSENE FLOW RATES IN FUNCTION OF TIME IN NON-EXTINCTION LIMIT TEST

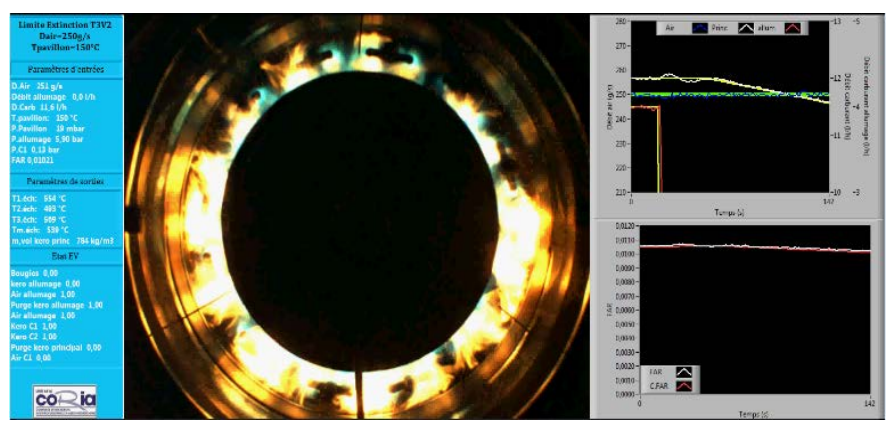

FIGURE 13. REBUILT VIDEO WITH MAIN PARAMETERS VARIATION FOR CONTROLLING

Figure 14 shows different annular chamber snapshots resulted from the kerosene non-extinction limit. It is to be noted that non-extinction flow of kerosene varies between $0.61-0.85 \mathrm{l} / \mathrm{h}$. For high precision, Coriolis technology has been used to measure this rate. The recommended range is from 0 to $100 \mathrm{l} / \mathrm{h}$. Between 0 and 1 $\mathrm{l} / \mathrm{h}$, the measurement error increases from $0.1 \%$ to $0.25 \%$ of full scale, which means a rate error of $0.12 \mathrm{l} / \mathrm{h}$. The dispersion of results can be explained by the uncertainty in testing. Indeed, the calculated average of different extinction flows is $0.74 \mathrm{l} / \mathrm{h}$. Taking into account the measurement uncertainty of $0.12 \mathrm{l} / \mathrm{h}$, the value of nonextinction limit rate is situated between 0.62 and $0.86 \mathrm{l} / \mathrm{h}$.

\section{LEARNING OUTCOMES ANALYSIS}

In this part, assessment of learning outcomes such as quantitative results from the conducted surveys by INSA, and other information are presented, in order to measure the laboratory exercise effectiveness in the engineering curriculum. These results have been determined by the head of quality in INSA who provides every year detailed reports showing important statistics to ensure the quality of courses. They are also responsible of tracking graduate and undergraduate students; hiring rate, 
average engineer's salary, and number of students in higher degrees studies.

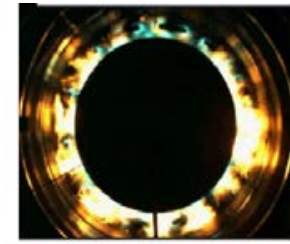

$\begin{array}{lc}\text { Kerosene (I/h) } & 12 \\ \text { Time (s) } & 0\end{array}$

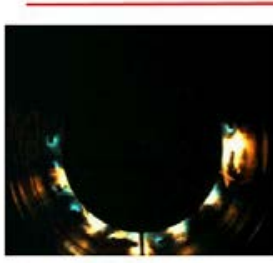

Kerosene (I/h) 4.2

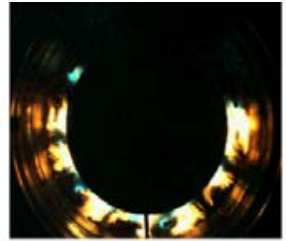

7.1
76

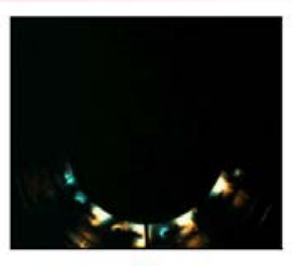

612

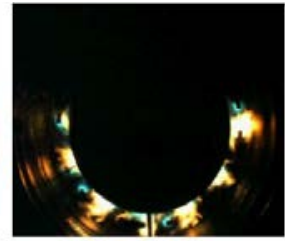

5
177

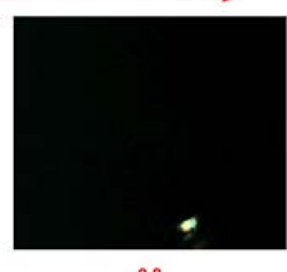

0.8
1044
FIGURE 14. CAPTURED IMAGES FROM THE NONEXTINCTION LIMIT TEST

It is important in this stage, to measure the outcomes on two levels. First, the mandatory industry-related project, which is a part of the 4th year course of EP (Energy and Propulsion) department. ALICE subject has been introduced for the first time in 2009 as an academic project with the goal of building an advanced test rig. The results of the surveys shows that 17 out of 29 students participated in ALICE construction ended up working in research and development in aeronautics or related field. For instance, Mr. Julien L. (2012-INSA graduate and technical leader at SAFRAN combustion chamber head office) said ALICE to be a rich experience and motivating element in the training of engineers. Today, he is responsible of supplying INSA with the latest test rigs in the aeronautics field for academic purpose.

Figure 15 shows the evolution in number of students pursuing doctoral studies in EP over the last years. Significant increase in doctoral pursuit has been noticed, the growth coincide with the implementation of 'research in education' strategy followed by EP, and the establishment of many industrial partnerships over the last years (ALICE is part of those taken actions), but no explicit conclusion can be made in a direct link with ALICE. In fact, many factors have to be taken into account. However, this is a good indicator of the positive influence of a research facility in engineers training. As explained previously, the laboratory exercise has been implemented in the 5th year 1st semester inside the aeronautics propulsion unit. The practical exercise comes along with 4 intense courses in turbojet engines, advanced gas dynamics and innovative propulsion methods. The objective of this unit is to prepare engineers with strong theoretical knowledge in specific areas of aeronautics which requires development of sharp skills in propulsion engines. Thanks to the advanced instrumentation and equipment of ALICE; students are able to carry out the needed skills in short time and with high efficiency. The efficiency here is expressed with the fact that ALICE comes in direct connection with class lessons via a hands-on approach. The high automation and instrumentation enables students to do many experiments and make observations in short time. The fact that ALICE is a full-scale rig with an industrial partner, motivates students to do their best, this observation is based on the overtime that students have spent on ALICE to reach their own goals. The facility has begun to operate as a laboratory exercise in 2015 . Therefore, there is a lack of quantitative assessment on this subject. However, the following collected data shows students' opinions on the laboratory exercise (Fig.16).

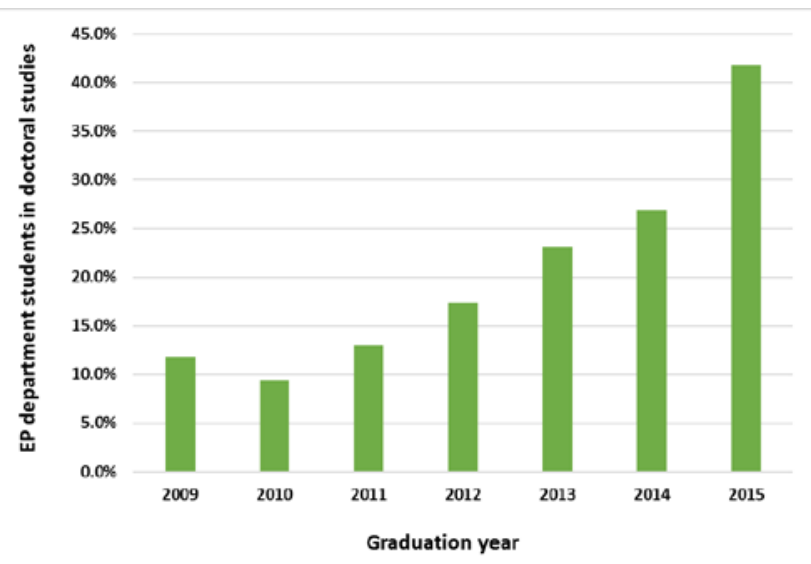

FIGURE 15. EVOLUTION IN NUMBER OF STUDENTS IN DOCTORAL STUDIES

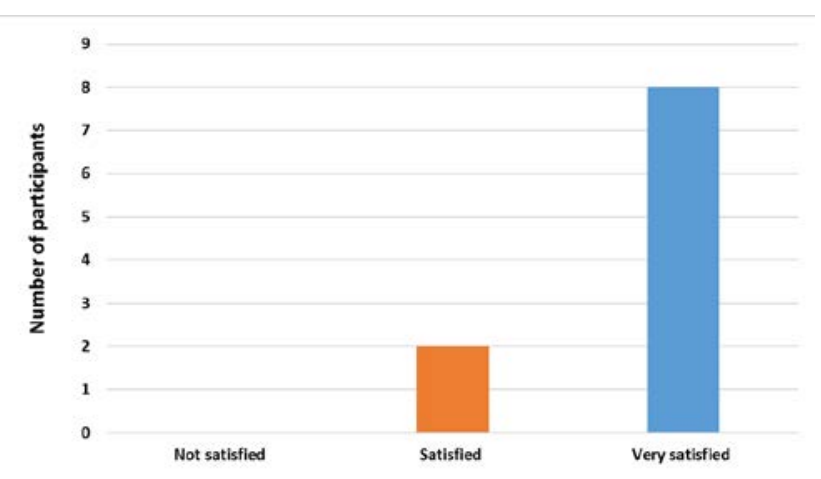

FIGURE 16. STUDENTS' ASSESSMENT (2015-2016) 


\section{CONCLUSIONS}

Advanced test bench for annular combustion chamber has been conceived by the students of INSARouen ( $4^{\text {th }}$ and $5^{\text {th }}$ year) and in cooperation with SAFRAN $\mathrm{HE}$. The facility is highly instrumented, automated and operational at an industrial scale. Moreover, ALICE is modular and compatible with a wide range of annular combustion chambers. Furthermore, ALICE has been successfully implemented and used in a course on turbojet engine in INSA-Rouen as a laboratory exercise for the $5^{\text {th }}$ year students. They have been spending a total of 8 hours on the test bench since few years. Experiences from working on it are excellent and the desired outcomes were fulfilled. Indeed, Introducing research into undergraduate engineering curricula has brought about satisfaction for participating undergraduates' learning goals. From the teacher perspective, an improved time effectiveness of the laboratory exercise when compared to classical laboratory activities is achieved. Undergraduates' participation in the project was an advantage as it was an opportunity for the students to apply acquired theoretical notions. Consequently, the development of the facility carries forward to future years. The assessment of the outcomes has been shown in the last section. Clearly, there is a lack of information to evaluate the outcomes of the laboratory exercise since it has been operating only for 2 years (2015). However, results from the mandatory industrialrelated project surveys show positive influence of the work on the quality of the study program.

\section{AKNOWLEDGEMENTS}

The authors are especially thankful for contributions SAFRAN HE. Appreciation is also expressed to colleagues from INSA Rouen-Normandie who contributed to the construction of the facility.

\section{REFERENCES}

[1] Boyer Commission, 1998, Reinventing Undergraduate Education : A Blueprint for America's Research Universities., State University of New York at Stony Brook for the Carnegie Foundation for the Advancement of Teaching.

[2] National Science Foundation Committee for the Review of Undergraduate Education, 1996, Shaping the Future: New Expectations for Undergraduate Education in Science, Mathematics, Engineering, and Technology (NSF 96-139).

[3] National Research Council, 1999, Transforming Undergraduate Education in Science, Mathematics, Engineering, and Technology, National Academies
Press.

[4] Kinkead, J., 2003, "Learning Through Inquiry: An Overview of Undergraduate Research," New Dir. Teach. Learn., (93), pp. 5-18.

[5] Hakim, T., 1998, "Soft Assessment of Undergraduate Research: Reactions and Student Perspectives.," Counc. Undergrad. Res. Q., 18, pp. 189-192.

[6] M. Kardash, C., 2000, "Evaluation of Undergraduate Research Experience: Perceptions of Undergraduate Interns and Their Faculty Mentors," J. Educ. Psychol., 92, pp. 191-201.

[7] Zydney, A. L., Bennett, J. S., Shahid, A., and Bauer, K., 2002, "Faculty Perspectives Regarding the Undergraduate Research Experience in Science and Engineering," J. Eng. Educ., 91(3), pp. 291-297.

[8] Zydney, A. L., Bennett, J. S., Shahid, A., and Bauer, K. W., 2002, "Impact of Undergraduate Research Experience in Engineering," J. Eng. Educ., 91(2), pp. 151-157.

[9] Morley, R. L., Havick, J. J., and May, G. S., 1998, “An Evaluation of the Georgia Tech Summer Undergraduate Program of Research in Electrical Engineering for Minorities," J. Eng. Educ., 87(3), pp. 321-325.

[10] "Plateforme E-Learning Moodle de l'INSA de Rouen" [Online]. Available: https://moodle.insa-rouen.fr/.

[11] Grisch, F., Boukhalfa, A., Cabot, G., Renou, B., and Vandel, A., 2016, "Coria Aeronautical Combustion Facilities and Associated Optical Diagnostics," Aerosp. Lab J., pp. AL11-02.

[12] Monaco, L., Vogt, D., and Fransson, T., 2013, "Implementation of a Remote Pump Laboratory Exercise in the Training of Engineering Students," Proceeding of the ASME Turbo Expo Meeting, Copenhagen, Denmark, pp. GT2012-69983.

[13] Whitacker, L. H. L., Tomita, J. T., and Bringhenti, C., 2017, "Project-Based Learning Applied in Turbopump Discipline at ITA Using 1D and 3D Numerical Simulations of a Booster Turbine Installed in the Space Shuttle Main Engine," Proceeding of the ASME Turbo Expo Meeting, Charlotte, North Carolina, USA, pp. GT2017-65058.

[14] Rouser, K. P., Thorn, C. R., Byerley, A. R., Wisniewski, C. F., Nowlin, S. R., and Van Treuren, K. W., 2013, "Integration of a Turbine Cascade Facility Into an Undergraduate Thermo-Propulsion Sequence," Proceeding of the ASME Turbo Expo Meeting, San Antonio, Texas, USA, pp. GT201394744.

[15] Turner, M. G., Rumpfkeil, M. P., VanKuren, J. T., Roberts, R. A., Bons, J., Smith, T., Ausserer, J. K., and Litke, P., 2013, "Thrust Vectoring Design Project at Six Universities: Part I - Project Description and Final Designs," Proceeding of the ASME Turbo Expo Meeting, San Antonio, Texas, USA, pp. GT2013- 
95602.

[16] Rumpfkeil, M. P., Turner, M. G., VanKuren, J. T., Roberts, R., Bons, J., Smith, T., and Ausserer, J. K., 2013, "Thrust Vectoring Design Project at Six Universities: Part II - Impact on Student Learning and Lessons Learned," Proceeding of the ASME Turbo Expo Meeting, San Antonio, Texas, USA, pp. GT2013-95631.

[17] Rouser, K. P., 2017, "Oral Assessments of Student Learning in Undergraduate Aerospace Propulsion and Power Courses," Proceeding of the ASME Turbo Expo Meeting, Charlotte, North Carolina, USA, pp. GT2017-64082.

[18] Leong, C. H., Jacob, J., and Liou, W., "Development of a Turbojet Engine Lab For Propulsion Education," 40th AIAA/ASME/SAE/ASEE Joint Propulsion Conference and Exhibit, American Institute of Aeronautics and Astronautics.

[19] Juste, G., Montañés, J. L., and Velazquez, A., 2008, "Micro-Jet Test Facility for Aerospace Propulsion Engineering Education," Int. J. Eng. Educ., 25(1), pp. 11-16.

[20] "Mini Gas Turbine Lab | Educational Gas Turbine Jet Engine" [Online]. Available: http://www.turbinetechnologies.com/educationallab-products/turbojet-engine-lab\#4345-technicalpapers.

[21] Lefebvre, A. H., 1998, GAS Turbine Combustion, Second Edition, CRC Press. 